\section{Морфологічні зміни щитоподібної залози щурів після введення триптофану}

Р.В. Янко

Інститут фізіології ім. О.О. Богомольця НАН України

Резюме. Попри добре вивчену роль триптофану в організмі, літературні дані відносно його впливу на морфофункціональний стан щитоподібної залози (ЩЗ) поодинокі й неоднозначні. Переважно досліджували концентрацію тиреоїдних гормонів у крові після введення триптофану. Водночас морфологічні зміни щЗ при його впливі залишаються мало дослідженими. Мета - дослідження морфологічних змін щ3 щурів після введення їм триптофану. Матеріал і методи. Дослідження проведено на 24 щурах-самцях лінії Wistar 3-місячного віку. Щури всіх груп перебували в уніфікованих умовах, на стандартному раціоні. Тварини дослідної групи щодня, протягом 28 діб, перорально отримували L-триптофан (Франція) в дозі 80 мг/кг. Підготовку тварин до експериментів та інвазивне втручання проводили згідно з принципами Гельсінської декларації. 3 центральних ділянок тканини ЩЗ виготовляли гістологічні препарати за стандартною методикою. 3 використанням цифрової камери мікропрепарати фотографували на мікроскопі «Nikon Eclipse E100» («Nikon Instruments Inc.», Японія). Морфометрію здійснювали за допомогою комп'ютерної програми «lmageJ». Статистичну обробку здійснювали методами варіаційної статистики. Результати. При гістологічному аналізі Щ3 щурів, які отримували L-триптофан, виявлено, що залоза має незмінену фізіологічну структуру. Фолікули переважно овальної форми та різних розмірів. Колоїд у фолікулах помірної щільності та містить численні резорбційні вакуолі. Тиреоцити призматичної та кубічної форми. Виявлено зменшення площі фолікулів, колоїду, їх внутрішнього діаметра, зростання стереологічного індексу резорбції та фолікулярно-колоїдного індексу і зниження індексу накопичення колоїду. Також відмічено зниження відносної площі строми в залозі, стромально-паренхіматозного індексу, ширини прошарків міжчасткової, міжчасточкової та міжфолікулярної сполучної тканини. Висновки. Довготривале (протягом 28 діб) введення щурам L-триптофану в дозі 80 мг/кг призводить до появи морфологічних ознак активації ЩЗ.

Ключові слова: щитоподібна залоза, триптофан, морфологія.

Триптофан є незамінною амінокислотою, яка входить до складу білків усіх живих організмів [1]. Триптофан використовують клітини ссавців для біосинтезу нікотинової кислоти () Р.В. Янко (вітамін РР), серотоніну і мелатоніну, м'язових білків і білків антитіл імунної системи $[2,3]$. Ця амінокислота нормалізує роботу нервової системи й травлення, має антидепресантну дію, підвищує опірність стресам і поліпшує сон [4]. 
Триптофан регулює функцію ендокринної системи (зокрема, стимулює соматотропну функцію гіпофіза), запобігає розвитку анемії, (оскільки відповідає за синтез гемоглобіну) і регулює кров’яний тиск $[5,6]$.

Проте, хоч роль триптофану в організмі добре вивчена, літературні дані відносно його впливу на стан ЩЗ поодинокі та неоднозначні. Переважно досліджували концентрацію тиреоїдних гормонів у крові після додаткового введення триптофану, чи навпаки - при його дефіциті в харчовому раціоні [7, 8]. Разом із тим вплив триптофану на морфологічні зміни Щ3 залишається мало дослідженим. На результати застосування триптофану в експериментальній практиці істотний вплив мають, з одного боку, дозування і тривалість введення амінокислоти, а з іншого - вік і стать експериментальних тварин. На сьогодні відсутні будьякі відомості про механізми та особливості впливу триптофану на морфо-функціональні показники стану ЩЗ.

Метою роботи було дослідити морфологічні зміни ЩЗ щурів після введення триптофану.

\section{Матеріал і методи}

Дослідження проведено на 24 щурах-самцях лінії Wistar 3-місячного віку. Щури всіх груп перебували в уніфікованих умовах, на стандартному раціоні. Тварини були розподілені на 2 групи: 1-а група - контрольні щури, 2-а група - дослідні тварини, які щодня перорально отримували L-триптофан (Франція) в дозі 80 мг/кг. Тривалість експерименту становила 28 діб. Щурів декапітували під легким ефірним наркозом.

3 центральних ділянок тканини Щ3 виготовляли гістологічні препарати за стандартною методикою: фіксували в рідині Буена, зневоднювали в спиртах зростальної концентрації (від 70 до 96 ) і діоксані. Отримані зразки заливали в парафін. Парафінові зрізи товщиною 5-6 мкм, виготовляли на санному мікротомі, фарбували гематоксиліном Бемера й еозином. Для візуалізації елементів сполучної тканини застосовували метод забарвлення по Ван-Гізону [9]. 3 використанням цифрової камери мікропрепарати фотографували на мікроскопі «Nikon Eclipse E100» («Nikon Instruments Inc.», Японія). Морфометрію здійсню- вали за допомогою комп'ютерної програми «Image J».

На гістологічних зрізах ЩЗ вимірювали площу поперечного перерізу фолікулів, колоїду і фолікулярного епітелію; зовнішній і внутрішній діаметри фолікулів; висоту фолікулярного епітелію. Підраховували середню кількість тиреоцитів у фолікулах. Визначали фолікулярно-колоїдний індекс (відношення площі фолікулярного епітелію до площі колоїду), стереологічний індекс резорбції $(4 / \mathrm{h}$, де $\mathrm{h}-$ середня довжина хорд відрізків ліній, що припадають на колоїд) і індекс накопичення колоїду (відношення середнього внутрішнього діаметра до подвійної висоти тиреоїдного епітелію). За використанням методу накладання точкових морфометричних сіток обчислювали відносну площу сполучної тканини, паренхіми залози, визначали стромально-паренхіматозний індекс (відношення відносної площі строми до відносної площі паренхіми залози). Вимірювали ширину прошарків міжчасткової, міжчасточкової і міжфолікулярної сполучної тканини [10, 11].

Підготовку тварин до експериментів та інвазивне втручання проводили згідно з вимогами «Європейської Конвенції про захист хребетних тварин, що використовуються для дослідних та інших наукових цілей» від 18.03.1986 р., Законом України «Про захист тварин від жорстокого поводження» № 3447IV від 21.02.2006 р. і Наказом Міністерства освіти і науки України «Про затвердження Порядку проведення науковими установами дослідів, експериментів на тваринах» № 249 від 01.03.2012 р.

Статистичну обробку здійснювали методами варіаційної статистики за допомогою комп'ютерної програми Statistica 6.0. Hормальність розподілу цифрових масивів перевіряли, використовуючи критерій Пірсона. Для оцінки вірогідності різниці між контрольною і дослідною групами використовували $t$-критерій Стьюдента. Відмінності вважали вірогідними при значенні $\mathrm{p}<0,05$.

\section{Результати та обговорення}

При гістологічному аналізі ЩЗ щурів, після введення їм L-триптофану, виявлено, що вона має незмінену фізіологічну структуру. 

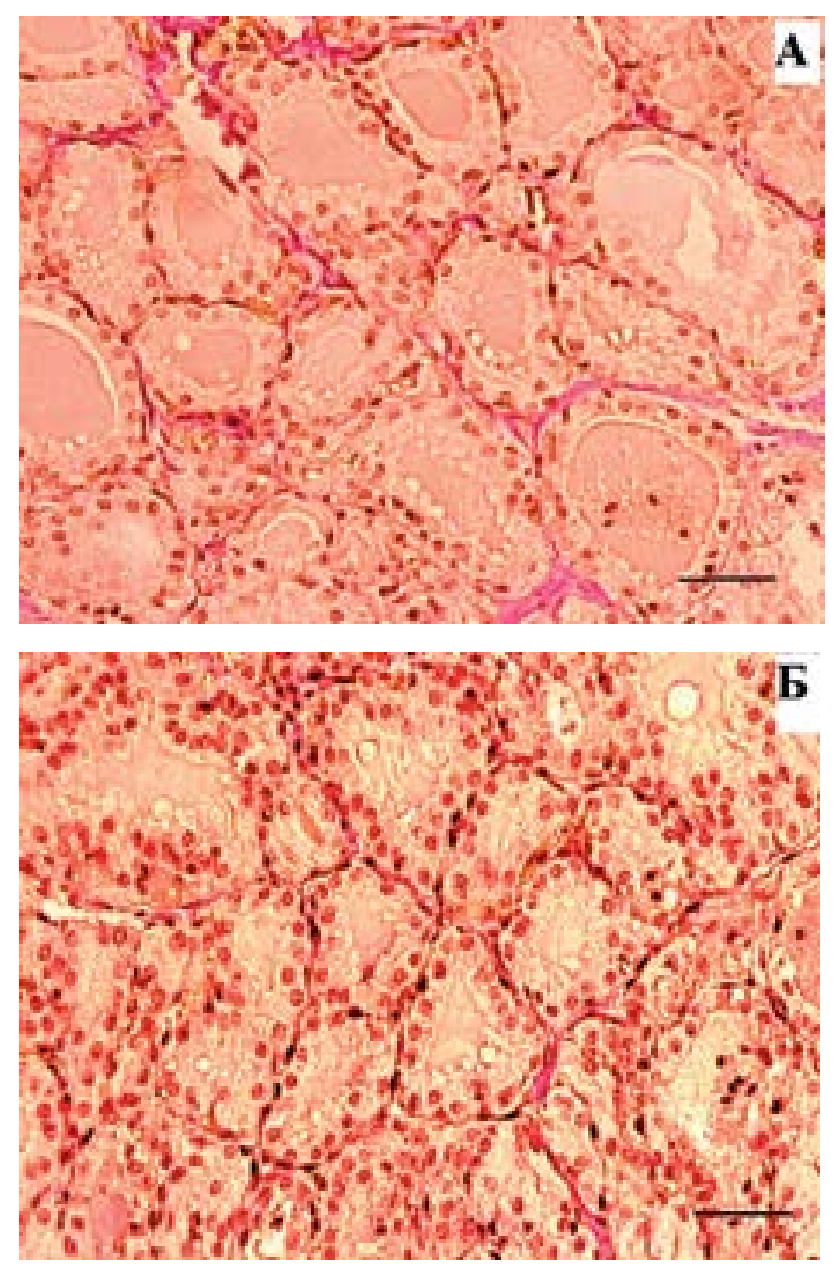

Рис. Мікрофотографія зрізу ЩЗ контрольної тварини (А) та щура після введення триптофану (Б).

Примітка: Риска - 50 мкм. Забарвлення по Ван-Гізону. ×400.

Fig. Microphotographs of the thyroid gland of control rat (A) and rat after tryptophan administration (Б)

Note: Bar $-50 \mu m$. Van Gieson stain. $\times 400$.

Фолікули в залозі мають переважно овальну форму та різні розміри. Колоїд у фолікулах дослідних тварин помірної щільності та містить численні резорбційні вакуолі. Тиреоцити мають призматичну та кубічну форму (рис.).

Абсолютна та відносна маси ЩЗ щурів після введення триптофану вірогідно не відрізнялися від контрольних показників (табл. 1).

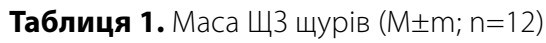

Table 1. Mass of the rat thyroid gland ( $M \pm m ; n=12)$

\begin{tabular}{|c|c|c|}
\hline $\begin{array}{l}\text { Показники } \\
\text { Parameters }\end{array}$ & $\begin{array}{l}\text { Контроль } \\
\text { Control }\end{array}$ & $\begin{array}{l}\text { Триптофан } \\
\text { Tryptophan }\end{array}$ \\
\hline $\begin{array}{l}\text { Абсолютна маса (мг) } \\
\text { Absolute mass, mg }\end{array}$ & $23 \pm 0,6$ & $22 \pm 0,7$ \\
\hline $\begin{array}{l}\text { Відносна маса (мг/г маси тіла) } \\
\text { Relative mass, mg/g body weight }\end{array}$ & $0,056 \pm 0,005$ & $0,057 \pm 0,004$ \\
\hline
\end{tabular}

У щурів, які отримували L-триптофан, виявили тенденцію до зростання відносної площі паренхіми Щ3 (на 7\%), а також вірогідне зниження середньої площі поперечного перерізу фолікулів (на 17\%), колоїду (на 20\%) і фолікулярного епітелію (на 15\%). Внутрішній діаметр фолікулів зменшився на 11\% (табл. 2).

Таблиця 2. Морфометричні показники паренхіми ЩЗ щурів $(\mathrm{M} \pm \mathrm{m} ; \mathrm{n}=12)$

Table 2. Morphometric parameters of the rat thyroid parenchyma $(\mathrm{M} \pm \mathrm{m} ; \mathrm{n}=12)$

\begin{tabular}{|c|c|c|}
\hline $\begin{array}{l}\text { Показники } \\
\text { Parameters }\end{array}$ & $\begin{array}{l}\text { Контроль } \\
\text { Control }\end{array}$ & $\begin{array}{l}\text { Триптофан } \\
\text { Tryptophan }\end{array}$ \\
\hline $\begin{array}{l}\text { Відносна площа (\%) } \\
\text { The relative area,\% } \\
\text { Площа }\left(\text { мкм²): }^{2} \text { Area, } \mu m^{2} \text { : }\right.\end{array}$ & $76,8 \pm 1,6$ & $82,3 \pm 0,7$ \\
\hline $\begin{array}{l}\text { фолікула } \\
\text { follicle }\end{array}$ & $2675 \pm 75$ & $2226 \pm 91^{*}$ \\
\hline $\begin{array}{l}\text { колоїду } \\
\text { colloid }\end{array}$ & $945 \pm 56$ & $752 \pm 32^{*}$ \\
\hline $\begin{array}{l}\text { фолікулярного епітелію } \\
\text { follicular epithelium }\end{array}$ & $1730 \pm 80$ & $1474 \pm 45^{*}$ \\
\hline Діаметр фолікула (мкм) & & \\
\hline Follicle diameter, $\mu \mathrm{m}$ & & \\
\hline $\begin{array}{l}\text { зовнішній } \\
\text { external }\end{array}$ & $52,0 \pm 1,2$ & $48,5 \pm 0,8$ \\
\hline $\begin{array}{l}\text { внутрішній } \\
\text { interior }\end{array}$ & $29,6 \pm 0,9$ & $26,2 \pm 0,6^{*}$ \\
\hline $\begin{array}{l}\text { Висота тиреоцитів (мкм) } \\
\text { The height of thyrocytes, } \mu \mathrm{m}\end{array}$ & $11,2 \pm 0,3$ & $11,2 \pm 0,2$ \\
\hline $\begin{array}{l}\text { Фолікулярно-колоїдний індекс } \\
\text { Follicular colloid index }\end{array}$ & $1,83 \pm 0,12$ & $1,96 \pm 0,07$ \\
\hline $\begin{array}{l}\text { Індекс накопичення колоїду } \\
\text { Colloid accumulation index }\end{array}$ & $1,32 \pm 0,09$ & $1,17 \pm 0,02$ \\
\hline $\begin{array}{l}\text { Стереологічний індекс резорбції } \\
\text { Stereological index of resorption }\end{array}$ & $0,135 \pm 0,002$ & $0,153 \pm 0,031^{*}$ \\
\hline $\begin{array}{l}\text { Кількість тироцитів у фолікулі (шт.) } \\
\text { The number of thyrocytes in the } \\
\text { follicle, pcs }\end{array}$ & $21,8 \pm 0,6$ & $20,0 \pm 0,4$ \\
\hline
\end{tabular}

Примітка: * - $p<0,05$ вірогідна різниця з контролем

Note: ${ }^{*}-p<0.05$ significant difference vs. control

Зменшення розмірів фолікулів та їх внутрішнього діаметра свідчить про зростання активності ЩЗ, резорбції тиреоглобуліну та вивільнення тиреоїдних гормонів у кровоносне русло [10, 12].

У щурів, які отримували L-триптофан, виявлено вірогідне зростання стереологічного індексу резорбції на 13\%. Цей показник характеризує динаміку накопичення і виведення інтрафолікулярного колоїду. Фолікулярноколоїдний індекс (індекс активності ЩЗ) у дослідних тварин мав тенденцію до зростання на 
7\%, а індекс накопичення колоїду (індекс Брауна), навпаки, був меншим від контролю на 11\% (табл. 2).

Як правило, функціональна активність Щ3 прямо пропорційна відносній площі фолікулярного епітелію й обернено пропорційна вмісту колоїду. Зростання стереологічного індексу резорбції та фолікулярно-колоїдного індексу свідчить про збільшення активності Щ3. Індекс накопичення колоїду, навпаки, знижується при активації залози $[10,13]$.

У ЩЗ дослідних тварин виявили вірогідне зниження відносної площі строми та стромально-паренхіматозного індексу на 24 і $27 \%$ відповідно (табл. 3).

таблиця 3. Морфометричні показники сполучної тканини Щз щурів (M $\pm m ; n=12)$

Table 3. Morphometric parameters of the rat thyroid connective tissue $(M \pm m ; n=12)$

\begin{tabular}{|c|c|c|}
\hline $\begin{array}{l}\text { Показники } \\
\text { Parameters }\end{array}$ & $\begin{array}{l}\text { Контроль } \\
\text { Control }\end{array}$ & $\begin{array}{l}\text { Триптофан } \\
\text { Tryptophan }\end{array}$ \\
\hline $\begin{array}{l}\text { Відносна площа (\%) } \\
\text { The relative area,\% }\end{array}$ & $23,2 \pm 1,6$ & $17,7 \pm 0,7^{*}$ \\
\hline $\begin{array}{l}\text { Стромально-паренхіматозний } \\
\text { індекс } \\
\text { Stromal and parenchymal index } \\
\text { Ширина прошарків сполучної } \\
\text { тканини (мкм): } \\
\text { The width of connective tissue } \\
\text { interlayers, } \mu \text { m: }\end{array}$ & $0,30 \pm 0,02$ & $0,22 \pm 0,01^{*}$ \\
\hline $\begin{array}{l}\text { міжчасткова } \\
\text { interlobar }\end{array}$ & $22,3 \pm 1,5$ & $20,7 \pm 1,6$ \\
\hline $\begin{array}{l}\text { міжчасточкова } \\
\text { interlobular }\end{array}$ & $10,8 \pm 0,3$ & $9,8 \pm 0,6$ \\
\hline $\begin{array}{l}\text { міжфолікулярна } \\
\text { interfollicular }\end{array}$ & $1,96 \pm 0,14$ & $1,87 \pm 0,08$ \\
\hline
\end{tabular}

Примітка: див. примітки до таблиці 2.

Note: see notes for Table 2.

Зменшення кількості сполучної тканини в ЩЗ є ознакою активації іï функції та зростання регенераторних можливостей. На активацію процесів фолікулогенезу в дослідних щурів може вказувати й зростання кількості інтерфолікулярних острівців, які містять малодиференційовані клітини - джерело для формування нових фолікулів [14, 15].

Дослідники переважно вивчали гормональний стан Щ3 після введення L-триптофану. Так, в експериментах на приматах виявлено, що однократне введення L-триптофану не призводить до змін базальних рівнів гормонів Щ3, але зменшує тироліберинову індукцію синтезу тиреотропіну [16]. Повторне введення триптофану збільшує концентрацію серотоніну в крові та трийодтироніну в плазмі та водночас знижує концентрацію тиреотропіну в плазмі тварин. Вважають, що такий ефект триптофану є результатом підвищення рівня серотоніну в ЩЗ, що призводить до збільшення концентрації трийодтироніну з компенсаторним зниженням тиреотропіну через негативний зворотний зв’язок.

В іншій роботі показано, що одноразове введення L-триптофану в дозі 120, 240 і 480 мг/кг маси тіла стимулює секрецію тиреоїдних гормонів у ягнят [7]. Виявлено, що при хронічному введенні L-триптофану в дозі 100 мг/кг протягом 7 днів знижується рівень тиреотропіну в крові в щурів різного віку [17].

Інші автори досліджували дефіцит L-триптофану $(0,115$ і $0,058 \%)$ в раціоні курчат на активність Щ3 [8]. Виявлено, що рівень трийодтироніну в плазмі був підвищений у курчат із дефіцитом триптофану, порівняно 3 контрольною групою, де його вміст становив 0,23\%. При цьому, рівень тироксину в плазмі був знижений, а маса ЩЗ і діаметр фолікулів не змінювалися. Така неоднозначність в отриманих результатах вимагає більш детального вивчення ролі та механізмів впливу триптофану на Щ3.

\section{Висновки}

Довготривале (протягом 28 діб) введення щурам L-триптофану в дозі 80 мг/кг призводить до появи морфологічних ознак активації ЩЗ, а саме: зростання стереологічного індексу резорбції та фолікулярно-колоїдного індексу, зниження індексу накопичення колоїду, зменшення розмірів фолікулів та їх внутрішнього діаметра, розмірів колоїду та кількості сполучної тканини в залозі.

\section{Список використаної літератури}

1. Palego L, Betti L, Rossi A, Giannaccini G. Tryptophan biochemistry: structural, nutritional, metabolic, and medical aspects in humans. J Amino Acids. 2016;2016:8952520.

2. Sanger GJ. 5-hydroxytryptamine and the gastrointestinal tract: where next? Trends Pharmacol Sci. 2008 Sep;29(9):465-71.

3. Thor PJ, Krolczyk G, Gil K, Zurowski D, Nowak L. Melatonin and serotonin effects on gastrointestinal motility. J Physiol Pharmacol. 2007 Dec;58 Suppl 6:97-103.

4. Fusar-Poli P, Allen P, McGuire P, Placentino A, Cortesi M, Perez J. Neuroimaging and electrophysiological studies of the effects of acute tryptophan depletion: a systematic review of the literature. Psychopharmacology (Berl). 2006 Oct;188(2):131-43. 
5. Lehnert H, Beyer J. Cardiovascular and endocrine properties of L-tryptophan in combination with various diets. Adv Exp Med Biol. 1991;294:407-16.

6. Kasuya E, Yayou K, Hashizume T, Kitagawa S, Sutoh M. A possible role of central serotonin in L-tryptophan-induced GH secretion in cattle. Anim Sci J. 2010 Jun;81(3):345-51.

7. Shokr EB, Touhidi A, Khazali H, Zhandi M. The effect of L-tryptophan on growth hormone and thyroid hormones secretion in growing lambs. J Vet Res. 2006;61(2):175-79.

8. Carew LB Jr, Alster FA, Foss DC, Scanes CG. Effect of a tryptophan deficiency on thyroid gland, growth hormone and testicular functions in chickens. J Nutr. 1983 Sep;113(9):1756-65.

9. Malatesta M. Histological and histochemical methods - Theory and practice. Eur J Histochem. 2016 Feb 29;60(1):2639.

10. Никишин ДВ. Морфология и методы исследования щитовидной железы: методические рекомендации. Пенза: Инф. - изд. центр ПГУ, 2008. 64 с. (Nikishin DV. Morphology and methods of thyroid research: methodical recommendations. Penza: Inf. of publ. center PGU, 2008. 64 p. Russian).

11. Янко РВ. Вплив метіоніну на морфологічні зміни щитоподібної залози щурів. Ендокринологія. 2019;24(1):41-5 (Yanko RV. The effect of methionine on the morphological changes of the thyroid gland of rats. Endokrynologia. 2019;24(1):41-5. Ukrainian).

12. Yanko RV, Levashov MI. Effect of interval fasting on morphological changes in the rat thyroid gland of different age. Biological Sciences of Kazakhstan. 2021; 1:8-18.

13. Юлдашева ФЗ, Юлдашев АЮ, Исмаилов СИ, Рашитов ММ Ультраструктурная характеристика тиреоцитов при гипои гиперфункции щитовидной железы. Международный эндокринолгический журнал. 2011;35(3):132-5 (Yuldasheva FZ, Yuldashev AYu, Ismailov SI, Rashitov MM. Ultrastructural description of thyreocytes in thyroid hypo- and hyperactivity International Journal of Endocrinology. 2011;35(3):132-5. Russian),

14. Aleshin BV, Brindak OI, Mamina VV. Correlations between the functional activity and proliferation of the thyroid parenchyma. The proliferative forms of the parenchyma of the thyroid. Probl Endokrinol (Mosk). 1987 Nov-Dec;33(6):67-72.

15. Khan YS, Farhana A. Histology, Thyroid Gland. [Updated 2021 May 10]. In: StatPearls [Internet]. Treasure Island (FL): StatPearls Publishing; 2021 Jan-. Available from: https://www.ncbi.nlm.nih. gov/books/NBK551659/

16. Morley JE, Raleigh MJ, Brammer GL, Yuwiler A, Geller E, Flannery J, Hershman JM. Serotonergic and catecholaminergic influence on thyroid function in the vervet monkey. Eur J Pharmacol. 1980 Oct 17;67(2-3):283-8.

17. Masalova OO. L-tryptophan modulates behavioral processes at disbalance of thyroid hormones. Eur Neuropsychopharmacol. 2005;15(Suppl 2): S107-8.

\section{Morphological changes in the rat thyroid gland after tryptophan administration}

\section{R.V. Yanko}

O.O. Bogomoletz Institute of Physiology of the National Academy of Sciences of Ukraine

Abstract. Despite the well-studied role of tryptophan in the body, the literature data of its effect on the morpho-functional state of the thyroid gland are single and ambiguous. Preferably, the concentration of thyroid hormones in the blood after the tryptophan administration was studied. At the same time, the morphological changes in the thyroid under its influence remain little studied. The aim of the study was to investigate the morphological changes in the rat thyroid gland after tryptophan administration. Material and methods. The study was carried out on 24 male Wistar rats aged 3 months. Rats of all groups were under uniform conditions and standard diet. Animals of the experimental group, daily for 28 days, orally received L-tryptophan (France) at a dose of $80 \mathrm{mg} / \mathrm{kg}$. Preparation of animals for experiments and invasive intervention were carried out in accordance with the principles of the Helsinki Declaration. Histological preparations were made from the central areas of the thyroid tissue by the standard method. The micropreparations were photographed using a digital camera of Nikon Microscope ECLIPSE E100 («Nikon Instruments Inc.», Japan). Morphometry was performed using a computer program «lmage J». Statistical processing was carried out by methods of variation statistics. Results. An unchanged physiological structure of the rat thyroid gland was revealed in animals taking L-tryptophan by histological analysis. The follicles had mostly the oval shape and various sizes. The follicular colloid was of moderate density with numerous resorption vacuoles. Thyrocytes had prismatic and cubic form. It was found a decrease of the follicular area, colloid, their inner diameter, and an increase in the stereological index of resorption and follicular-colloidal index and decrease of the colloid accumulation index. It noted also that there was the decrease of relative area of the stroma in the gland, the stromalparenchymal index, the width of the interlobar, interlobular and interfollicular connective tissue. Conclusions. Prolonged (28 days) administration of L-tryptophan (at a dose of $80 \mathrm{mg} / \mathrm{kg}$ ) to rats leads to the appearance of morphological signs of thyroid activation.

Keywords: thyroid gland, tryptophan, morphology.

\section{Морфологические изменения щитовидной железы крыс после введения триптофана}

\section{Р.В. Янко}

Институт физиологии им. А.А. Богомольца НАН Украины

Резюме. Несмотря на хорошо изученную роль триптофана в организме, литературные данные относительно его влияния на морфофункциональное состояние щитовидной железы (ЩЖ) единичные и неоднозначны. Преимущественно исследовали концентрацию тиреоидных гормонов в крови после введения триптофана. В то же время морфологические изменения ЩЖ при его воздействии остаются мало исследованными. Цель - исследование морфологических изменений ЩЖ крыс после введения им триптофана. Материал и методы. Исследование проведено на 24 крысах-самцах линии Wistar в возрасте 3-месяцев. Крысы всех групп находились в унифицированных условиях, на стандартном рационе питания. Жи вотные подопытной группы ежедневно, в течение 28 суток перорально получали L-триптофан (Франция) в дозе 80 мг/кг Подготовку животных к экспериментам и инвазивное вмешательство проводили согласно принципам Хельсинской декларации. Из центральных участков ткани ЩЖ изготавливали гистологические препараты по стандартной методике. С использованием цифровой камеры микропрепараты фото- 
графировали на микроскопе «Nikon Eclipse E100» («Nikon Instruments Inc.», Япония). Морфометрию осуществляли с помощью компьютерной программы «lmage J». Статистическую обработку осуществляли методами вариационной статистики.

Результаты. При гистологическом анализе ЩЖ крыс, получавших L-триптофан, выявлено, что она имеет не измененную физиологическую структуру. Фолликулы преимущественно овальной формы и разных размеров. Коллоид в фолликулах подопытных животных умеренной плотности и содержит многочисленные резорбционные вакуоли. Тиреоциты призматической и кубической формы. Выявлено, что в ЩЖ крыс, после введения им триптофана, уменьшается площадь фолликулов, коллоида, их внутренний диаметр, возрастает стереологичный индекс резорбции и фолликулярно-коллоидный индекс и снижается индекс накопления коллоида. Также у подопытных животных отмечено снижение относительной площади стромы в железе, стромально-паренхиматозного индекса, ширины междолевой, междольковой и межфолликулярной соединительной ткани. Выводы. Длительное (28 дней) введение крысам L-триптофана (в дозе 80 мг/кг) приводит к появлению морфологических признаков активации щитовидной железы.

Ключевые слова: щитовидная железа, триптофан, морфология.

Для цитування: Янко РВ. Морфологічні зміни щитоподібної залози щурів після введення триптофану. Ендокринологія 2021;26(3):281-286. DOI: 10.31793/1680-1466.2021.26-3.281.

Адреса для листування: Янко Роман Васильович; biolag@ukr. net; Інститут фізіології ім. О.О. Богомольця НАН України; Київ, вул. Богомольця, 4, 01024, Україна.

Відомості про автора: Янко Роман Васильович, канд. біол. наук, старший науковий співробітник відділу клінічної фізіології сполучної тканини, ORCID: 0000-0002-0397-7517.

Особистий внесок: Янко Р.В. - повна підготовка статті.

Фінансування: робота виконана в рамках державного завдання «ннститут фізіології ім. О.О. Богомольця НАН України» (№ 0119U103965), а також частково за рахунок коштів НАН України для підтримки розвитку пріоритетних напрямків досліджень СРН (№ 0118U007344).

Декларація з етики: автор задекларував відсутність конфлікту інтересів і фінансових зобов'язань.
Стаття надійшла до редакції 21.07.2021 р.; перероблена 30.07.2021 р.; прийнята до друку 01.10.2021 р.; надрукована 20.10.2021 p.

For citation: Yanko RV. Morphological changes in the rat thyroid gland after tryptophan administration. Endokrynologia. 2021;26(3):281-286. DOI: 10.31793/1680-1466.2021.26-3.281.

Correspondence address: Roman Yanko; biolag@ukr.net; O.O. Bogomoletz Institute of Physiology of NAS of Ukraine; Kyiv, Bogomoletz st., 4, 01024, Ukraine.

Information about the author: Roman Yanko, Cand. Sci. (Biology), Senior Researcher, Department of Clinical Physiology of Connective Tissue, ORCID: 0000-0002-0397-7517.

Personal contribution: Yanko RV — full editing an article.

Funding: the work was performed as part of the state assignment «O.O. Bogomoletz Institute of Physiology of NAS of Ukraine» (No. 0116U004472), and partly from funds of the National Academy of Sciences of Ukraine to support the development of priority areas of research SRN (state registration number) 0118 U007344.

Declaration of ethics: the author declared the absence of a conflict of interest and financial obligation.

Article: received 21 July 2021; revised 30 July 2021; accepted 01 October 2021; published 20 October 2021.

Для цитирования: Янко РВ. Морфологические изменения щитовидной железы крыс после введения триптофана. Эндокринология. 2021;26(3):281-286. DOI: 10.31793/16801466.2021.26-3.281.

Адрес для переписки: Янко Роман Васильевич; biolag@ukr. net; Институт физиологии им. А.А. Богомольца НАН Украины, Киев, ул. Богомольца, 4, 01024, Украина.

Сведения об авторе: Янко Роман Васильевич, канд. биол. наук, старший научный сотрудник отдела клинической физиологии соединительной ткани, ORCID: 0000-0002-0397-7517.

Личный вклад: Янко РВ - полная подготовка статьи.

Финансирование: работа выполнена в рамках государственного задания «Институт физиологии им. А.А. Богомольца НАН Украины» (№ 0119U103965), а также частично за счёт средств НАН Украины для поддержки развития приоритетных направлений исследований СРН (№ 0118U007344).

Декларация по этике: автор задекларировал отсутствие конфликта интересов и финансовых обязательств.

Статья: поступила в редакцию 21.07.2021 г.; переработана 30.07.2021 г.; принята в печать 01.10.2021 г.; напечатана 20.10.2021 г. 